\title{
Mineralization of Rare Earths, Platinum and Gold in a Sedimentary Deposit, Found Using an Indirect Method of Exploration
}

\author{
Eduardo Cerecdeo-Sáenz ${ }^{1}$, Ventura Rodríguez-Lugo' ${ }^{1}$, Juan Hernández Ávila ${ }^{1}$, Demetrio Mendoza- Anaya ${ }^{2}$, Ma \\ Isabel Reyes-Valderrama ${ }^{1}$, Emiliano Moreno-Pérez ${ }^{1}$ and Eleazar Salinas-Rodríguez ${ }^{1 *}$
}

${ }^{1}$ Mineral of the Reformation, University of the State of Hidalgo, Mexico

${ }^{2}$ National Institute of Nuclear Research, Mexico

*Corresponding author: Eleazar Salinas-Rodríguez, Mineral of the Reformation, University of the State of Hidalgo, Mineral of the Reformation, Hidalgo, Mexico

Submission: 眥 January 27, 2018; Published: 海 February 27, 2018

\begin{abstract}
This work shows the unpublished occurrence of a preliminary mineralization of Rare Earths, Platinum and Gold, in a sedimentary outcrop of Jurassic Lower Pliensbachian. The location of this deposit was achieved by applying an indirect method of exploration based in the identification and analysis of sedimentary transgressions of heterochronies ages and the identification of a Rift - type mega -structure. According with the used methodology, it was carried out a study of the discordant relationships between two types of sediments: continental and marine, which represent an unpublished methodology used in researches related to mining exploration in Mexico (and could be used in other countries) and thus, was found the deposit which was wholly characterized in this work. The most important results found according the characterization done, show the existence of light rare earths, principally Y, La, Ce, Pr, Nd, Sm, Eu, Gd, Tb, Dy, Hm, Er, Tm and Yb, in values that show positive anomalies in comparison with the distribution of elements in upper continental crust according to the Clarke, reflecting so a felsic affinity of the mineral deposit. Also, positive anomalies of platinum, and Pd (observed by X-mapping), were determined with marginal contents of $\mathrm{Au}$ and $\mathrm{Ag}$ (determined by X-Ray mappings); and finally the base metals $\mathrm{Zn}, \mathrm{Pb}$ and $\mathrm{Cu}$ were detected in low contents, which could be due to the presence of altered shale. According to the sedimentary lithology found, which was of siliciclastic type; to the exhalative roots observed during the fieldwork; the presence of quartz minerals such as biotite and muscovite; the presence of minerals of hydrothermal remobilization like chalcopyrite with some base metals of $\mathrm{Zn}, \mathrm{Cu}, \mathrm{Pb}$, altered shale, as well as sulfur deficiency; this mineral reservoir could be defined as a SEDEX-Type.
\end{abstract}

Keywords: Rare earths; Platinum; SEDEX ore body; Rift mega structure; transgression

\section{Introduction}

Geological-mining exploration has been based on direct methods that include an orientation survey, stream sediment geochemistry, sampling gas and, where applicable, a series of drillings in sites previously located, based on the results obtained in the previous stages. All this, represents both a great economic investment as well as time.

Using the mentioned method, until the mid-90s had been located in western Mexico about 60 deposits of Volcanogenic Massive Sulfurs (VMS) [1] mostly, and others sedimentary exhalative (SEDEX), found in upper Jurassic- Cretaceous rocks and forming clusters. These deposits were located mainly in the "Terreno Guerrero" (GT) [2], and most of these deposits are of oceanic affinity with base metals such as $\mathrm{Zn}-\mathrm{Pb}-\mathrm{Cu}$; of the KUKOKO type like the "Tizapa" [3], with about 100,000 Tons to 6 MT; in Guanajuato and Baja California with 1 MT having contents of base metals of $\mathrm{Zn}-\mathrm{Cu}$ of the kind COPPER KING [1].
On the other hand, SEDEX deposits whit continental affinity lie in the complex Arteaga in Michoacan and in the metamorphic complex of Xolapa, [4], and are of Pb-type with reserves of $2 \mathrm{MT}$, and in Zacatecas which is the largest with $36 \mathrm{MT}$; also it is important to note that both Zacatecas and Guanajuato [1], have low contents of Ag with some enrichment of Au.

The main features of the VMS [3] and SEDEX deposits are scarcely known in Mexico, as well as other sedimentary deposits that have been studied recently and have been exploited in artisan way, because its main economic attractiveness is due to the contents of $\mathrm{Cu}$ and $\mathrm{Ag}$ that they could have. The fact that Mexico has traditionally been a silver producing country, led the search only in this metal rich deposits that were mainly epithermal and mesothermal igneous type from Ternary; so marine and continental sedimentary deposits of low contents of Ag, have had little attention, and also these deposits could have base metals such as $\mathrm{Cu}, \mathrm{Pb}, \mathrm{Zn}$, with contents of $\mathrm{Au}$ and $\mathrm{Ag}$ in small quantities [5]. Similarly, the 
techniques of extraction of ores igneous epi and meso-thermal having higher silver content, have been the most studied so far, and have had little or no effectiveness with the synergetic deposits sedimentary considered marginal by the low contents of Ag, without considering that it may contain other metals accessories that give added value to this type of deposits. However, advances in the study of new processes for extracting metal values has achieved effective results in the extraction of $\mathrm{Au}, \mathrm{Ag}$ and $\mathrm{Cu}$ from reservoirs with low values of these metals [6], and considering the large volumes of sedimentary deposits, has become a profitable exploitation.

In eastern Mexico there is a giant syngenetic manganese deposit of marine affinity SEDEX-type [7] and it is considered as the largest deposit in north America of this kind [8] being a sample of the potential contents of minerals for this SEDEX-type deposits.

In the same way, the first intents to find rare earths in Mexico were related to the prospection of phosphorites located in eastern Mexico [9] mainly in Tamaulipas, reporting the presence of an intrusive of Ternary age of nefeline-foidolites and rare earths mineralization. On the other hand, some geochemical studies were carried out in precambric rocks from Mexico in the Grenvilliane basement of Huiznopala Gneiss [10], where were obtained positive anomalies of $\mathrm{Eu}$ and low concentrations of $\mathrm{Y}, \mathrm{Zr}, \mathrm{Nb}, \mathrm{Th}$ and $\mathrm{U}$, similarly to that reported in the Oaxaqueño Complex [11] located in the south east of Mexico.

As is known, the major occurrence of REE's is in Asia, being almost the $95 \%$ of total production in China. In this region is located the principal source of REE, which is the Bayan Obo deposits with high grade and igneous type that corresponds near to $80 \%$ of LREE's [12] but with low contents of HREE's.

It is important to note that actually the tendency is related to the production of HREE, due the corresponding deposits have more content of these elements, and mining and extractive processes are comparatively less expensive [13]. Another alternative for recovery of REE's are the marine nodules, which are located at a depth of 3 to $5 \mathrm{Km}[14]$ in the ocean.

According PGE's, its occurrence has been described in Yukon in Canada by [15], on the exploration of platinum from PGE in black slates where were explained deposits of different origins; the association of V-Cr-PGE's is known in exhalative deposits [16], and also chromium-spinels associated to Pd minerals have been described in Nairme, Australia [17] suggesting that PGE's anomalies have its origin in exhalative deposits related to volcanism in Rift zones, with some presence of organic matter.

The traditional methodology used in Mexico to locate mineral deposits such as igneous, epithermal, meso-thermal and sedimentary, has employed direct methods based in the primary delimitation of the area of study, through and exhaustive review of all sources of possible geological information. So, research can focus the study on the following main aspects: regional geology, the stratigraphy of the area, geochemistry to know principal alterations, tectonics to describe the structure and finally, the location of a zone to get drillings.
With the data obtained in the steps described above, the analysis of the deposits, after carrying out the study of geological, stratigraphic and structural data, supported by geophysical well logs, is performed. Indicating the formation (rock) of mining interest perforated thickness and upper and lower contacts, which is helpful to delineate the deposit, in time and space?

This method of exploration uses both direct and indirect dates that allow in many cases, to facilitate the work and reduce investment and time. However, this work introduces an innovation to those methods, which is the study and analysis of heterochronies transgressions, but in this case only was analyzed the proto Jurassic transgression of age Pleisbachiano [18], due to the nature of the sedimentary deposits that are exploited near to the area of study, but these belong to a Kinmerigiano age [8]. Finally, this work shows a novel methodology to find sedimentary deposits, and proposes an indirect method, which have given important results in previous works [19], where were considered the existence of anomalies for REE and precious metals such as Au Pt and Pd, in the east of Mexico, and the results were quite similar to those found in other deposits [20].

\section{Methods}

\section{Indirect method of mining exploration}

The methodology developed that innovate the traditional method of mining exploration to find in this case, sedimentary ore deposits, embraces some stage, which are: 1) A recompilation of all geological, geochemical and geophysical information available for the region of study, which will help to locate targets for the preliminary exploration. 2) To establish the different types of rocks and determine their relative ages, marking principally the transgressions and discordances, which is the basis of the proposed method, because this consists in the study of these transgressions, and suggests an evaluation of the discordant stratigraphic relationships of a marine transgression on rock of continental origin in a specific area. 3) To determine the main tectonic events in the area of study where is the transgression, for both compressive and extensive events, and then perform the tectonic analysis including erosion factors to locate the possible tectonic horst and graven, and this will link this tectonic event with the site of the transgressive event to find rocks with potential for the mining exploration. The favourable factors that transgressions offer to find the site of the mineralization are the following: Physiographic conditions of the graven, physicochemical conditions of the rock, conditions oxidation-reduction of the mineralized zone, and dissolution medium. 4) To define the primary and secondary environment of mineralization, using instrumental and geochemical analysis, in samples taken in the site located by the previous stages.

The prospecting method also provides guidelines to define regions with mining potential, defining the following: The amount of mining horizons producers for each geological formation, and if is always the same lithological unit or there are more, identification of lateral and vertical changes in the horizons or formations of minerals found and their physical recognition, defining the depth 
and thickness of producing horizons by lithology, and if they are lenses of sand or sandstone, identifying if their geological-mining behaviour is different; and finally defining if stratigraphic and structural configuration of these horizons of minerals is of interest.

\section{Characterization of mineral}

The characterization performed in this work was carried out to obtain accurate data of the mineralogical phase's present, for which was done an analysis of overall phases by This Polished Sections and $\mathrm{X}$ - Ray Diffraction (XRD) to confirm the mineral phases present. Also, the characterization studies were complemented by Scanning Electron Microscopy (SEM) to evaluate the texture, particle size and morphology of the phases detected, in the same way the X-ray mapping and EDS analysis helped us to determine punctual semi - quantitative composition of some previous phases identified and their distribution in particular zones. Finally, was conducted an analysis by ICP-MS, which gave the composition of whole rock and the obtained results were compared with the distribution of elements according to the Clarke.

\section{Results}

\section{Indirect method of mining exploration}

The most important of applying the indirect method previously described, is that this was useful to locate outcrops of sedimentary origin. All the raised and described methodology generated satisfactory results, considering that all elements described in the method were determined and thus the necessary clues that allowed finding the site of interest were obtained. The basis of the method proposed for the location of minerals was focuses on determining geological ages, the depths and the upwelling areas. The prospecting method provided further guidance to define regions with mining potential, considering that in the area of study was found only a mining horizon producer, located near the top of the Huayacocotla formation having an age of Pleinsbachiano-Lower Jurassic.

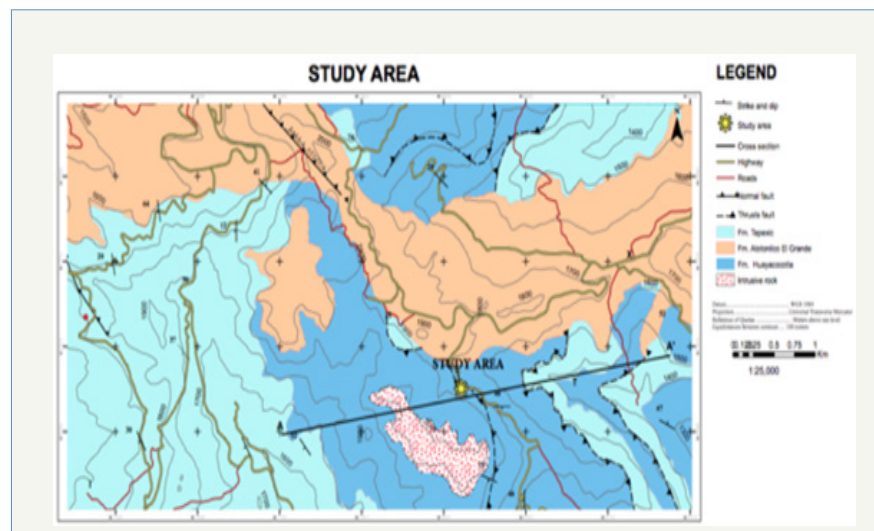

Figure 1: Geological map showing the study area.

The mineral deposit found (Figure 1) with the above methodology, was located at the following coordinates; Longitude: -98.700334325 and Latitude: 20.765593 where were observed two main types of mineralization (Figure 2), which shows the study area found by the indirect method, where the main transgressions that delimit the location of the site were identified. In the upper unit, siltstone is observed, but there is a sudden change in the colour of the shale into green tones and with remnants of organic matter, which is indicative again of a continental affinity, and was also observed strata of sandstone and conglomerate with clasts of less than $3 \mathrm{~cm}$ and outcrops of volcanic rock of intermediate to felsic composition; one located in a Philonian outcrop, having high solidification with finely disseminated pyrite throughout the matrix and exhalative roots.

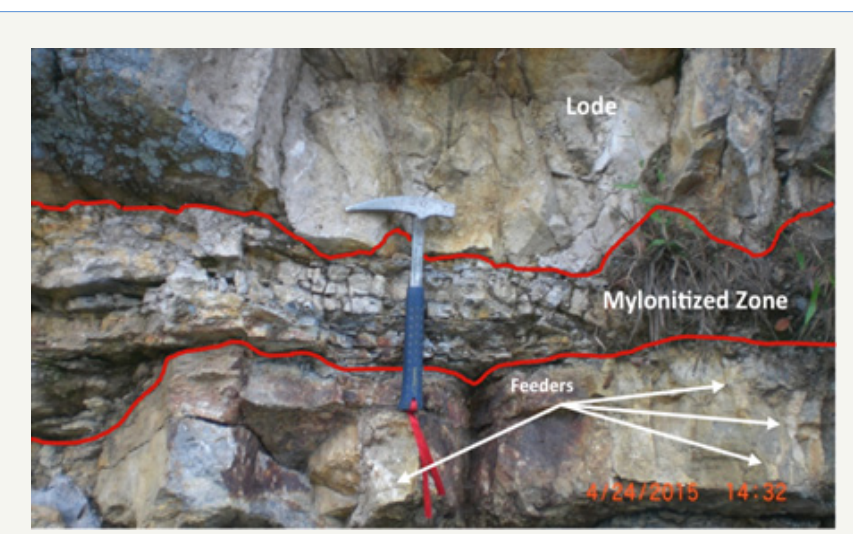

Figure 2: Two types of production units.

The other outcrop is a sequence of sedimentary rocks, showing alteration of minerals with granoblastic texture, siliciclastic and deformed pyrite. In the first type of outcrop, a hole of 9 meters deep was made on the basis of the observed stock-work structure, in which were detected the exhalative roots of outcrop and near to the contact, on the top of the transgressive sequence, as seen in Figure 3.

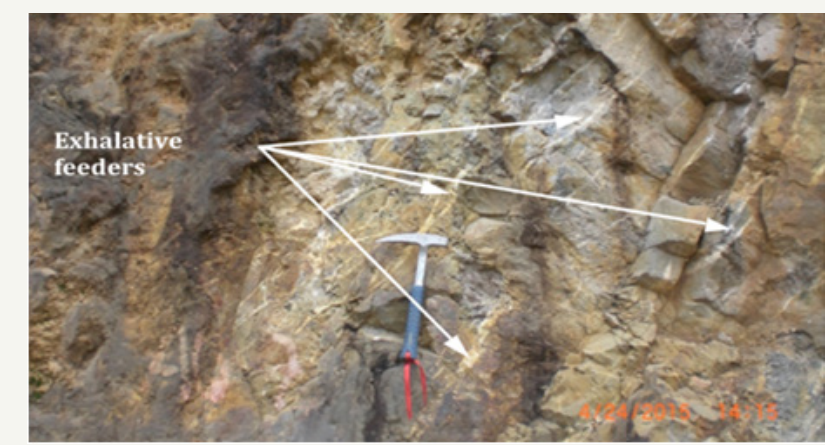

Figure 3: Outcrop of the deposit showing the exhalative feeders, which resemble a stock work structure.

However, in the initial portion of transgressive cycle, were located some exhalative roots such as seen in Figure 3 that shows the two lithologies of the producer unit. Also the base metal deposits were located only in the intermediate unit of the lithology transgressive showing shale and sandstone at rhythmic intervals, which overlies the shale unit with organic matter from the Huayacocotla Formation. Possibly at the base of the intermediate unit, are the outcropping exhalative roots that have not yet been charted. In the Huayacocotla Formation also three lithological units were recognized; the oldest consists of conglomerate, sandstone, siltstone, and shale intervals gap with re-worked fossils, exo-clasts sandstone, volcanic rock fragments and smaller proportions of 
limestone rocks. The size of the measured clasts was 5 to $100 \mathrm{~cm}$ in a sandy matrix and the size of the conglomerate clasts and clasts, suggest a continental affinity. The intermediate unit represents a marine transgression, because in the fieldwork was observed that this unit consists of sandstone and shale in a rhythmic sequence. In clusters, the size is not greater than $10 \mathrm{~cm}$ and the main feature of this unit, is the presence of marine ammonites at the base of the same, mainly in the shale. Near the top, the roots of the outcrop exhalative were observed.

In the area of study, thickness of 350 meters were measured at 900 meters from the Huayacocotla Formation and thickness of producer horizon surfaced 100 meters, and the upper unit shale with organic matter outcrops 250 meters from sedimentary rocks and increases in some areas with outcrops of volcanic rocks at 350 meters, the intermediate portion is greater than 250 meters thickness, while the basal portion was observed at about 450 meters. Figure 4 shows the lithological correlation of transgression of the lower Jurassic.

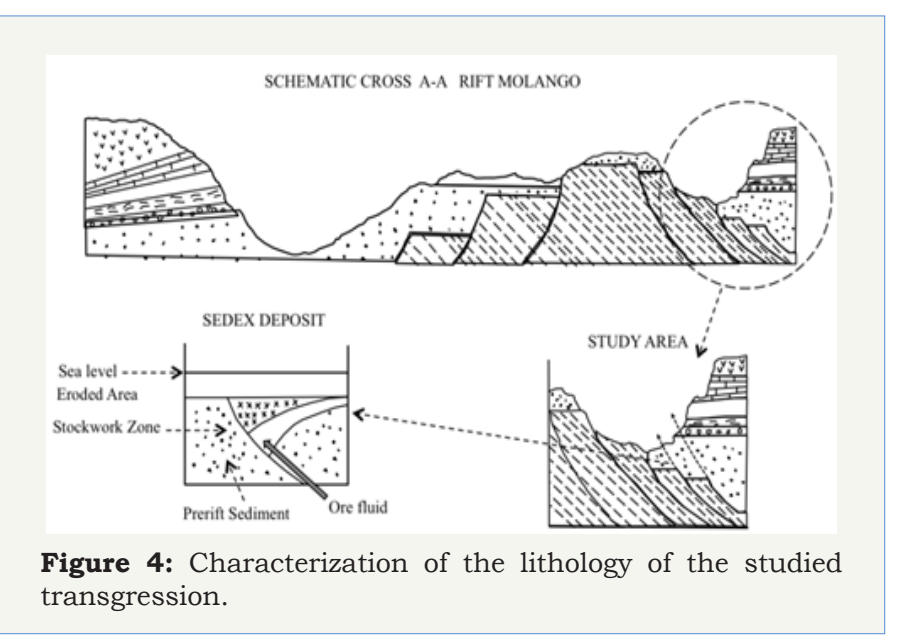

On the other hand, sandstone lenses were observed in the units, and some of them are rich in organic matter, indicating also an environment of continental deposit. The mining geological behaviour is different in the Huayacocotla training, since the mineralization is attributed here to the lithology of the intermediate portion and, it infra-lies to the shale with the organic matter unit. According stratigraphic setting, this is arranged in the form of bands NWSE direction, while the intermediate unit is structurally associated with high basement and related to areas of the reverse faults.

So, according the obtained results, it was possible to find two geological events of methodological type that allowed locate this ore deposit, which is due to tectonic environment and principally by the proto Jurassic Transgression. In the first case and according to megascopic study, could be observed rests of an antique Rift Triassic - Jurassic in eastern Mexico op. cit [21], and also is fundamental for understanding the mineralization control related in this work. This tectonic background, leads among others the metal dissolution medium that can be saline water and the conduction channels due to the topography, resulting in a litho-logical change from reductive to oxidant nature [22-24].
In the manganese district of Molango, is located the zone containing stratigraphic and structural vestiges that allowed infer an hetero-chronic stage of proto and neo Jurassic transgression, according [25,26], and that is associated to a SEDEX mineralization located in Cuba [16], having similar characteristics to the ore deposit found in this work.

Furthermore, structurally are observed evidences of a TriassicJurassic Rift in the zone of study [24] and whose base is of age Grenvillian, showing tectonic features similar to those observed in the North Qaidam Orogen, Western China. Likewise, it follows that the origin of base metal mineralization and rare earths, perhaps is related to pluvial sediments associated to hydrothermal activity linked to the Rift that could be the origin of the Gulf of Mexico [24]. This is important, because was widely accepted that sedimentary deposits (SEDEX) and other sedimentary strati form deposits occurred in this type of environment $[27,28]$.

\section{Characterization of the ore deposit}

The preliminary characterization of the deposit found, was based on the mineralogical description by Thin Polished sections, $\mathrm{XRD}$, and morphological identification, some specific semiquantitative analysis using SEM-EDS and X-ray mapping to identify the distribution of elements in samples taken throughout the depth of the blast-hole made from 0 to 9 meters. Finally, was conducted an analysis of whole rock by fire assay (ICP-MS).

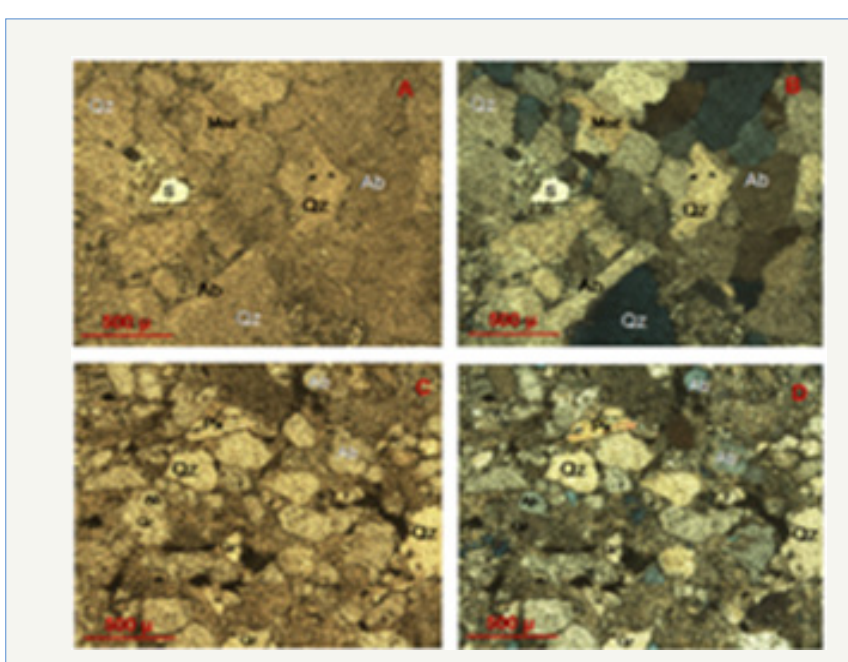

Figure 5: Polished thin sections A) parallel light (PL), 4x; B) cross-polarized light (CPL) 4x (Filonian material); C) PL, 4x; D) CPL, 4x (Sedimentary material).

Thin polished sections: Figure 5 shows the results observed in the thin polished section done. Figures $5 \mathrm{~A} \& 5 \mathrm{~B}$ correspond to a philonian material, which were examined with parallel light (5A) and cross nicols (5B); where from the matrix with angular to sub-angular clasts, was observed a replacement by quartz, possibly albite $(\mathrm{Ab})$ and the quartz $(\mathrm{Qz})$ showed in some fragments, undulating extinction which may be due to the fact that the material could be subjected to stress. In the images, also can be observed sulfur and some fragments of monazite (Moz) imbibed in a quartz matrix and the veins with dark minerals are parallel among them, but also are cut among themselves in the form of a stock-work. 
The Figure 5C was obtained with polarized light and Figure 5D with cross nicols, and both show angular to sub-angular minerals with sedimentary matrix of clasts with an average size of $26 \mu \mathrm{m}$, and also were observed quartz $(\mathrm{Qz})$, albite $(\mathrm{Ab})$ and pyroxene $(\mathrm{Px})$, quartz veins with dark minerals that partially replace the fluidallooking clasts. Also can be observed very fine fragments of monazite (Moz) near to the quartz veins.
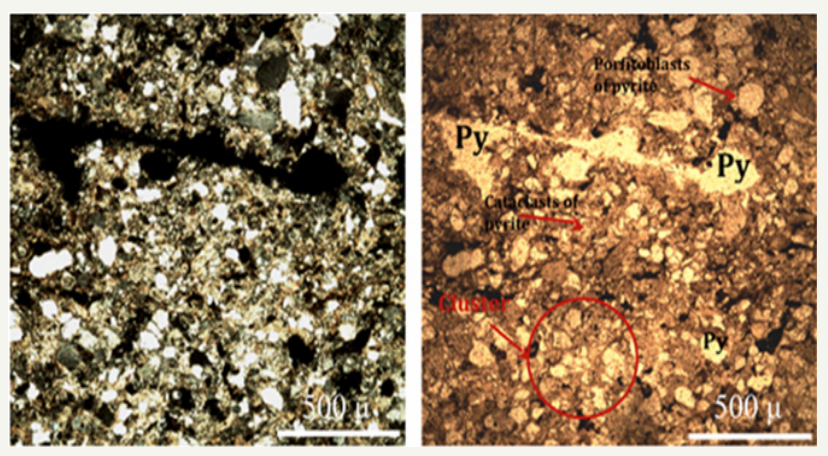

Figure 6: Polished thin section showing the presence of pyrite in various forms.

Finally, Figure 6 shows another polished section where was observed a collo-form texture that is in the center of metamorphic, porfiroblastic and cataclastic zones, found in a fault zone. In addition, in this sample the reduction of size by mechanical stresses of the pyrite in grains and the disintegration in the form of clusters of pyrite grains in the lower part of image.

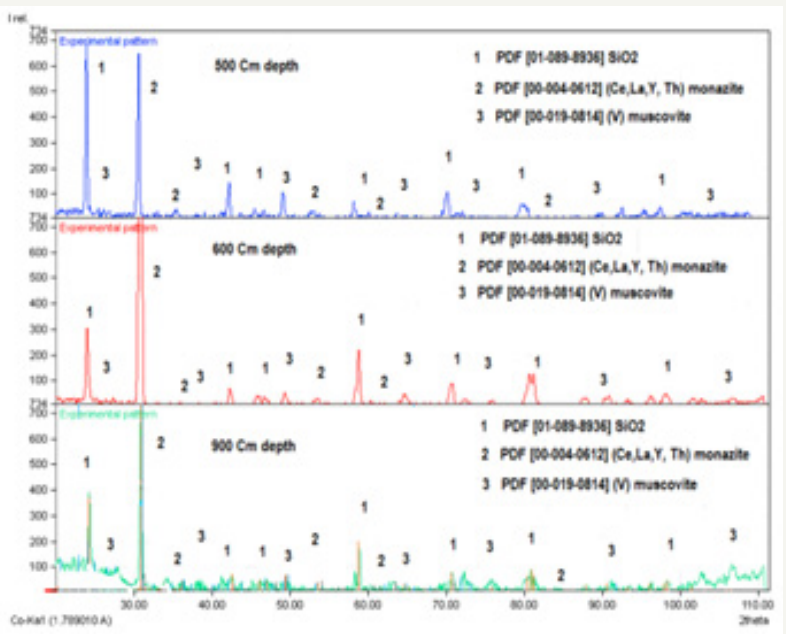

Figure 7: XDR spectrums, showing high and medium temperature minerals.

X-Ray diffraction: The XRD results are mainly shown in Figure 7, where the presence of minerals of high and medium temperature such as monazite, quartz type mogonite, muscovite and albite are observed for mineral taken at $500 \mathrm{~cm}$ depth. For high temperature minerals, it was noted the presence of illmenite that could be associated with the rare earths contents. Also, as depth increases the amount of quartz decreases and is remarket the presence of minerals like monazite and muscovite that are associated to rare earths, platinum, palladium and gold.

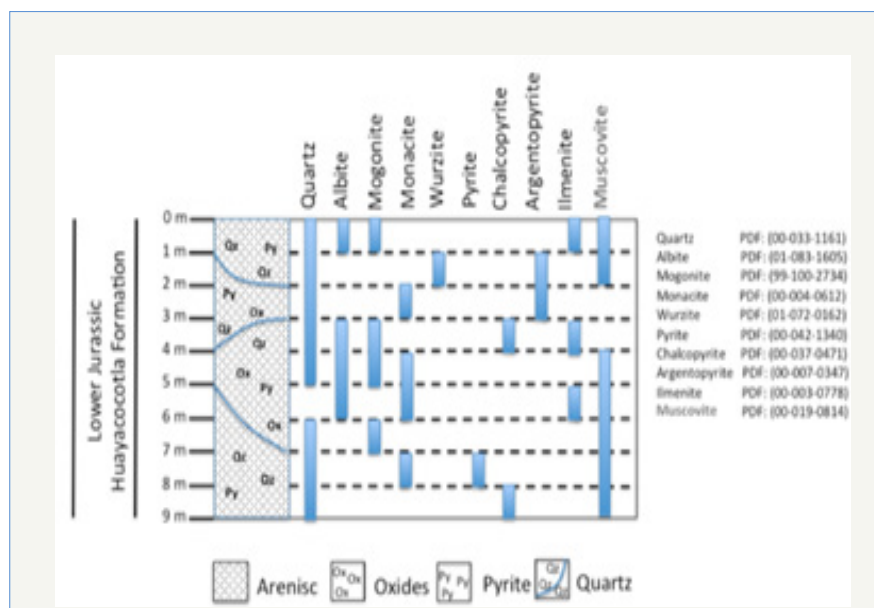

Figure 8: Distribution of minerals phases (by XRD) along the length of the drill core.

As a resume, Figure 8 shows the distribution of minerals by XRD from extracted core drilling. It can notice that there are minerals of high, medium and low temperature distributed through the lithological column, confirming the existence of thermal pulses.

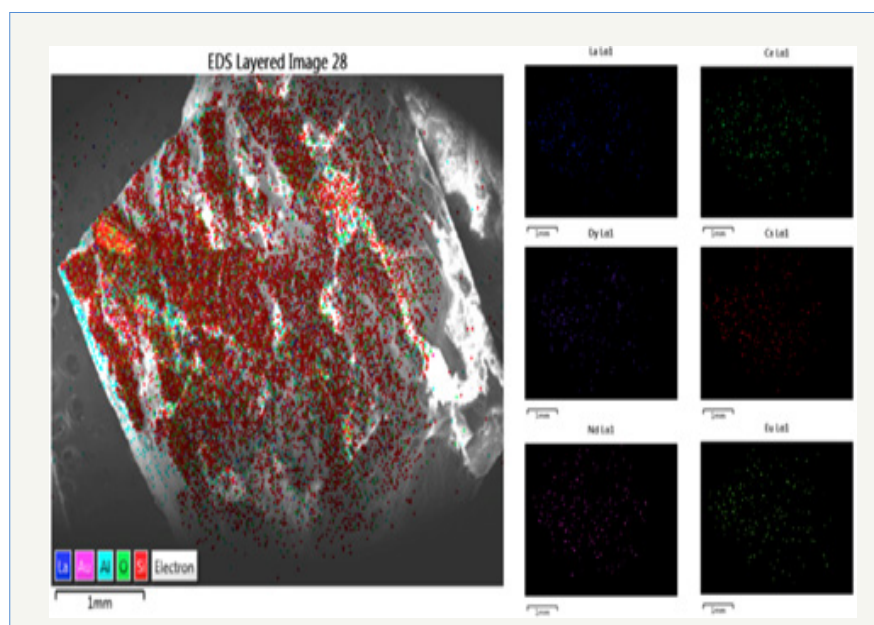

Figure 9: $\mathrm{X}$ - ray mapping (by SEM) of a characteristic particle showing some LREE content.

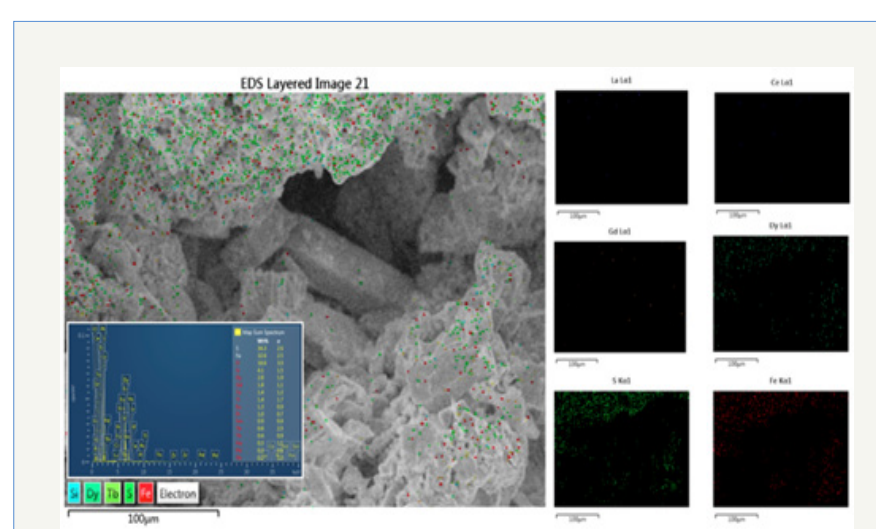

Figure 10: SEM image showing where EDS analysis was performed, the results of which are reported in Table 1.

Scanning electron microscopy: The characterization performed by scanning electron microscopy in conjunction with EDS and X-Ray mappings analysis allowed us to establish the 
presence of REE, Pt, Pd, $\mathrm{Au}$ and $\mathrm{Ag}$ in the most representative particles of the samples analyzed.

Figures $9 \& 10$ show a semi-detailed images of two particles of mineral, which were observed by mapping the overall distribution of the La, Ce, Dy, Cs, Nd, Eu, Gd, S and Fe. In Figure 10, can be observed that rare earths elements could be trapped during reduction of pyrite by adsorption due to possible production of vacancies in the pyrite botryoidal, and Table 1 shows the punctual analysis done by EDS of each site showed in Figure 10.

Table 1: General EDS results for each point noted in figure 10.

\begin{tabular}{|c|c|c|c|c|c|c|c|c|c|c|}
\hline \multirow{2}{*}{ Element } & \multicolumn{10}{|c|}{ Wt. \% } \\
\hline & General & 1 & 2 & 3 & 4 & 5 & 6 & 7 & 8 & 9 \\
\hline$S$ & 34.3 & 45.5 & 45.8 & 47 & 39.1 & 5.6 & 54.9 & 42.9 & 41.6 & 37 \\
\hline $\mathrm{Fe}$ & 32.6 & 54.5 & 46.8 & 53 & 58.2 & 5.8 & 45.1 & 30.5 & 35.8 & 63 \\
\hline 0 & 16.6 & - & - & - & - & 49.9 & - & - & 19.2 & - \\
\hline $\mathrm{Si}$ & 4.1 & - & 7.4 & - & 2.7 & 38.7 & - & 26.6 & 3.4 & - \\
\hline Dy & 2.8 & - & - & - & - & - & - & - & - & - \\
\hline Gd & 1.8 & - & - & - & - & - & - & - & - & - \\
\hline $\mathrm{Ta}$ & 1.4 & - & - & - & - & - & - & - & - & - \\
\hline $\mathrm{Tl}$ & 1.4 & - & - & - & - & - & - & - & - & - \\
\hline $\mathrm{Eu}$ & 1.3 & - & - & - & - & - & - & - & - & - \\
\hline $\operatorname{Pr}$ & 1 & - & - & - & - & - & - & - & - & - \\
\hline $\mathrm{Sm}$ & 0.9 & - & - & - & - & - & - & - & - & - \\
\hline $\mathrm{Tb}$ & 0.6 & - & - & - & - & - & - & - & - & - \\
\hline Th & 0.4 & - & - & - & - & - & - & - & - & - \\
\hline Ho & 0.3 & - & - & - & - & - & - & - & - & - \\
\hline $\mathrm{Pd}$ & 0.3 & - & - & - & - & - & - & - & - & - \\
\hline $\mathrm{Yb}$ & 0.2 & - & - & - & - & - & - & - & - & - \\
\hline
\end{tabular}

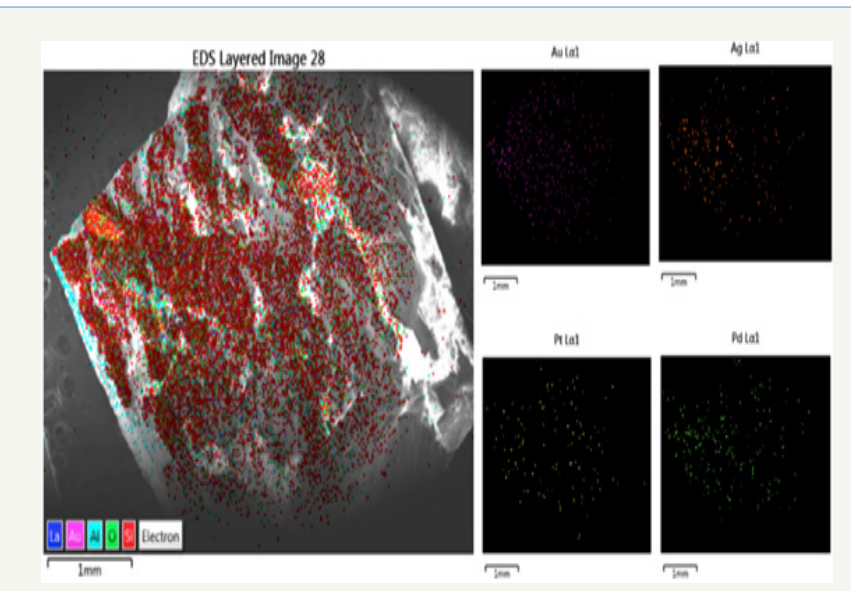

Figure 11: $\mathrm{X}$ - ray mapping of $\mathrm{Pt}, \mathrm{Pd}, \mathrm{Au}$ and $\mathrm{Ag}$ contained in a mineral particle (SEM).

Likewise, Figure 11 shows the mappings made in the same particle of Figure 9, to locate the presence and distribution of $\mathrm{Pt}, \mathrm{Pd}, \mathrm{Au}$ and Ag; which could be due to the formation of faults that generated channels where occurred a reduction process and then these elements flowed until were caught by the shale. The foregoing, together with the results of ICP-MS (whole rock) confirm the presence of these strategic elements in the type of deposit described here, which is the potential basis for considering this preliminary study, to find an economically attractive deposit near to this location or in the same site.
Table 2: Average distribution of elements in the Earth's crust according to Clarke [29].

\begin{tabular}{|c|c|}
\hline Range & Elements (\% orppm) \\
\hline Greaterthan $10 \%$ & $O(46.6), \operatorname{Si}(27.7)$ \\
\hline $1-10 \%$ & $\mathrm{Al}(8.1), \mathrm{Fe}(5.0), \mathrm{Ca}(3.6), \mathrm{K}(2.6), \mathrm{Na}(2.8), \mathrm{Mg}(2.1)$ \\
\hline $0.1-1 \%$ & $\mathrm{C}, \mathrm{H}, \mathrm{Mn}, \mathrm{P}, \mathrm{Ti}$ \\
\hline $10-100 \mathrm{ppm}$ & $\mathrm{Cu}, \mathrm{Ce}, \mathrm{Co}, \mathrm{Ga}, \mathrm{La}, \mathrm{Li}, \mathrm{Nb}, \mathrm{Ni}, \mathrm{Pb}, \mathrm{Sn}, \mathrm{Th}, \mathrm{Zn}, \mathrm{Y}$ \\
\hline $0.1-1 \mathrm{ppm}$ & $\begin{array}{c}\text { As, B, Br, Cs, Hf, Mo, Sb, Ta, U, W, Lanthanides, Bi, Cd, } \\
\text { Y, In, Tl }\end{array}$ \\
\hline $0.01-0.1 \mathrm{ppm}$ & $\mathrm{Ag}, \mathrm{Pd}, \mathrm{Se}$ \\
\hline $0.001-0.01 \mathrm{ppm}$ & $\mathrm{Au}, \mathrm{Ir}, \mathrm{Os}, \mathrm{Re}, \mathrm{Pt}, \mathrm{Rh}, \mathrm{Ru}$ \\
\hline
\end{tabular}

Table 3: Elements in samples that are above the average values according to Clarke [29].

\begin{tabular}{|c|c|}
\hline Range & Elements (\%) \\
\hline Greaterthan $10 \%$ & $\mathrm{Si}(40.8)$ \\
\hline $1-10 \%$ & $\mathrm{Fe}(36.6), \mathrm{Al}(6.2), \mathrm{K}(2.9), \mathrm{Mg}(1.72), \mathrm{Ca}(1.03)$ \\
\hline $0.1-1 \%$ & $\mathrm{Ti}(0.71), \mathrm{Mn}(0.52), \mathrm{P}(0.19)$ \\
\hline
\end{tabular}

Analysis by ICP-MS: The results obtained by ICP-MS were compared with the distribution of elements in the upper earth crust described by Clarke [29], which could be observed in Table 2. According to the obtained results, can be seen that the principal elements detected by ICP-MS have a positive anomalies with respect to the Clarke. Tables 3 show the chemical composition of the sample (whole rock) and can be seen that contents of rare earth 
elements and minor values of $\mathrm{Pt}, \mathrm{Pd}$ and $\mathrm{Au}$ are above the average contents according to the Clarke, which may represent an economic potential of this ore deposit found using a method of Indirect Mining Exploration, once mineral reserves can be determined.

\section{Discussion}

\section{Indirect method of mining exploration:}

The method of mining exploration here raised, is focused on prospecting mineralization in sedimentary rocks whose minerals preferably are housed in strata or related to these by stratigraphic relationships of marine transgressions, on rocks of continental origin and thus find and display susceptible traces that could contain mineralization in a given area. Although its application is related here only to sedimentary rocks, also it could indirectly be used to define other lithologies such as in igneous and metamorphic rocks, which may contain mineralization. In addition, it is noteworthy that the sedimentary deposits are widespread and they occur in all geological eras, from the Proterozoic to the present, and at different depths.

On the other hand, the secular variations in the abundance of sedimentary deposits, for example in the study area, are presented during the Lower Jurassic, but the abundance of occurrences also could be determined correlating with other mineral deposits of importance already in exploitation.

\section{Characterization of the ore deposit:}

In the geochemical analysis of trace elements such as $\mathrm{Cr}$ and $\mathrm{Th}$, due their low mobility, these are considered suitable for determining provenance and tectonic setting [30]. As seen from the results, there is an enrichment of elements large ion such as $\mathrm{Cr}=80 \mathrm{ppm}$ and $\mathrm{Th}=25 \mathrm{ppm}$; all are higher than the average contents of a Huayacocotla shale barren. On the other hand, the contents (in ppm) of transition trace elements $\mathrm{V}=89, \mathrm{Co}=15.8, \mathrm{Cu}=331$ and $\mathrm{Ni}=41.5$, are low due to that affinity of the deposit could be felsic or acid. Indeed, while the content of $\mathrm{Cr}$ and $\mathrm{Ni}$ is low, the content of $\mathrm{V}$ could be associated to the occurrence of metals such as platinum, palladium and gold.

Also this deposit has higher concentration of light rare earths (LREE) than the Clarke, because values (in ppm) for heavy rare earths (HREE) are low for $\mathrm{Y}=32.3$ and $\mathrm{Ga}=21$. For this reason, it could be inferred the presence of associated minerals of REE of the monazite-type (Ce, La, Nd, Th, (PO4)) and bastnaesite minerals.

It is important to note that negative anomaly of HREE for $\mathrm{Eu}$ and $\mathrm{Hf}$ with respect to Clarke, confirms the impoverishment of HREE and reaffirms the felsic affinity of the deposit, and the possibility that its origin is from a Gneissic protolithic, because mineralization has higher concentrations of LREE. In the same way, a negative anomaly of Ta shows a sedimentary affinity of the ore deposit. On the other hand, the negative anomaly of sulfur can be due to the presence of pyrite formed by sulfate reduction in marine environment of lower Jurassic age [31]. Also, the possible contents of organic carbon, the presence of pyrite in botryoidal aggregates, sulfur clasts, and low contents of base metals, low ratios of $\mathrm{Ag} / \mathrm{Au}$, and minor contents of arsenopyrite and pyrrhotite, could be to the silisticlastic nature that is typical of the Rift environments [27].

Likewise, the study area according to the obtained results could be classified as a Rift, such as was described by Jowet [22], showing besides a bimodal volcanism, fault-controlled guidelines, positive gravity, and rapid sedimentation rates over short periods of time that change at slow rates over long periods. In the same way, it is known $[32,33]$ that a Rift environment is conductive to the location of SEDEX deposits of base metals, such as described here.

Finally, the Huayacocotla Formation in which this deposit lies, have a great similarity in litho-logical, stratigraphic and chronological aspects with another deposit found in the San Cayetano Formation [20], which also was classified as a SEDEX and located in the Matahambres area of Cuba.

\section{Conclusion}

i. An innovative method of Mining Exploration was developed and evaluated through fieldwork, and with which a sedimentary deposit was found in the eastern of the Hidalgo state, in Mexico. This method, based in the study of transgressions has been called "Indirect Method of Mining Exploration".

ii. Mineralization found is strongly linked to a sedimentary control; besides is close related with a marine transgression of lower Jurassic age.

iii. The mineral outcrop found, consist of two types of mineralization. The first of the Philonian type, where exhalative roots of the stock-work type were observed at the base. And the second, of stratiform type formed by a sequence of sandstones and shale mutually concordant and of marine origin. This lithology, preliminary is the typical one found in several formations of type SEDEX.

iv. According to the characterization carried out by Thin Polished Sections, metamorphism and cataclastic fragments of mechanically deformed pyrite and quartz were found, which is indicative of the existence of old tectonism and the movement of transgressions. Likewise, minerals of reducing environment such as the pyrite that in this case was found in a botryoidal form, indicating so its marine origin. In the same way, it was possible to identify micro - veins filled with quartz and disseminated pyrite, remobilization minerals such as chalcopyrite and finally, monazite; all of them possibly originated in a stock-work.

v. From the analysis performed by ICP, as well as the complementary characterization carried out by XRD, SEM-EDS; it is concluded that the mineral found contains adequate values of precious metals such as $\mathrm{Au}, \mathrm{Ag}$, Pt and Pd, as well as some rare earths elements, since their values are above the average classification made by the Clarke.

vi. All of the above contributes to establish that depending on the results obtained; this outcrop is a SEDEX type deposit with possibilities to have mining potential. Also, these results validate the 
Indirect Method of Mining Exploration to find sedimentary deposits through the study of transgressions, but could be modified to find any type of deposit, based on its main lithological characteristics.

\section{Acknowledgement}

Authors want to thank to UAEH for the support given to the execution of this work, also thanks to the ININ for the cooperation during characterization of samples. Finally to PRODEP, for the financial support given for the publication of this paper.

\section{References}

1. Miranda GMA (1995) The volcanogenic massive sulfide and sedimentary exhalative deposits of the Guerrero Terrane, Mexico. The University of Arizona pp. 298.

2. Campa MF, Coney PJ (1983) Tectono-stratigraphic terranes and mineral resource distributions in Mexico. Canadian Journal Earth Science 20(6): 1040-1051

3. Akio Y, Koji K (2000) Geology of the Tizapa mine in Mexico with special reference to the present status after development, Shigen Chishitsu 50(2000): 1-10.

4. Hermann UR, Nelson BK, Ratsbacher L (1994) The origin of a terrane: $\mathrm{U} / \mathrm{Pb}$ zircon geochronology and tectonic evolution of Xolapa complex (southern Mexico). Tectonics, Vol. 13(2): 455-474.

5. Mortensen JK, Hall BV, Bissing T, Friedman RM, Dasnielson T et al (2008) Age and Paleotectonic Setting of Volcanogenic Massive Sulfide Deposits in the Guerrero Terrane of Central Mexico: Constrain from U-Pb Age Isotope Studies, Economic Geology 103(1): 117-140.

6. Salinas RE, Hernández AJ, Rivera LI, Cerecedo SE, Reyes VMI, et al. (2016) Leaching of silver contained in mining tailing, using sodium thiosulfate: A kinetic Study. Hydrometallurgy 160: 6-11.

7. Maynard BJ, Klein GD (1995) Tectonic Subsidence analysis in the Characterization of Sedimentary Ore Deposits: Examples from the Witwatersrand $(\mathrm{Au})$, White Pine $(\mathrm{Cu})$, and Molango $(\mathrm{Mn})$. Economic Geology 90(1): 37-50.

8. Okita PM (1992) Manganese Carbonate Mineralization in the Molango District, Mexico. Economic Geology 87(5): 1345-1366.

9. Herrera EM, Rubinovich KR, Lozano SCR, Sánchez ZJL (1991) Nephelinerich foidolites and rare earths mineralization in the picacho tertiary intrusive complex, sierra de Tamaulipas, north-eastern Mexico. Canadian Mineralogist 29(2): 319-336.

10. Lawlor PJ, Ortega-Gutierrez F, Cameron KL, Ochoa-Camarillo H, Lopez R, et al. (1999) U-Pb geochronology, geochemistry and provenance of the Grenvillian Huiznopala Gneiss of eastern Mexico. Precambrian Research 94(1-2): 73-99.

11. Keppie JD, Dostal J, Cameron KL, Solari L, Ortega-Gutierrez F, et al. (2003) Geochronology and geochemistry of Grenvillian igneous suites in the Northen Oaxacan Complex, Southern Mexico: tectonic implications. Precambrian Research 120(3-4): 365-389.

12. Verplanck PL, Van Gosen BS, Seal RR, McCafferty AE (2014) A deposit model for carbonatite and peralkaline intrusion - related rare earth element deposits, U.S.A Geological Survey Scientific Investigations Report 2010-5070-J, pp. 58.

13. Kynicky J, Smith MP, Xu C (2012) Diversity of rare earth deposits: the key example of China. Elements 8(5): 361-367.

14. Kato Y, Fujinaga K, Nakamura K, Takaya Y, Kitamura K, et al. (2011) Deep-sea mud in the Pacific Ocean as a potential resource for rare-earth elements. Nature Geoscience 4: 535-539.

15. Hulbert L, Carne R, Gregoire C, Paktunc D (1992) Sedimentary nickel, zinc, and platinum-group-mineralization in the Denovian black shale at the Nickel property, Yukon, Canada: a new deposit type. Expl Min Geol 1(1): 39-62.

16. Melgarejo JC (1997) Atlas of Mineral Associations in Thin Sheet: Mineral Associations in exhalative sediments and their metamorphic derivatives. Editions University of Barcelona (In Spanish) pp. 287-308.

17. Pasave J (1993) Anoxic sediments-an important environment for PGE; an overview. Ore Geol Rev 8(5): 425-445.

18. Erber HK (1956) The Middle Jurassic and the Callovian of Mexico: Mexico D.F. Congr Geol International (In Spanish) 20: pp. 393.

19. Cerecedo SE, Rodríguez LV, Andrade TPD, Salinas RE, Hernández AJ, et al. (2015) Chemistry and characterization of a mineral deposit mineralogical economic interest. Mater Res Soc Symp Proc pp. 1766

20. Perez VRG, Melgarejo JC (1998) El yacimiento Matahambre (Pinar del Río Cuba): Estructura y mineralogía. Acta Geológica Hispánica 33(1-4): 133-152.

21. Cerecedo SE (2003) La mineralización de cobre-plata del Rift TriásicoJurásico del oriente de México, Instituto Politécnico Nacional, Escuela Superior de Ingeniería y Arquitectura. Master Thesis pp. 284.

22. Jowet EC (1986) Effects of continental rifting on the location and genesis of stratiform copper-silver deposits. Geological Association of Canada 36: 53-66.

23. Goodfellow WD, Lydon JW, Turner RW (1993) Geology and genesis of stratiform sediment-hosted (SEDEX) Zn-Pb-Ag sulphide deposits, in Kirkham et al. (Eds.), Mineral Deposit Modeling, Geological Association of Canada 40: 201-251.

24. Cerecedo SE, Salinas RE (2013) Guía Rápida de Exploración Geológica Minera. Editorial Académica Española (In Spanish), Saarbrücken, Alemania, pp. 73.

25. Cantú CA (1998) Las transgresiones jurásicas en México. Revista Mexicana de Ciencias Geológicas (In Spanish) 15(1): 25-37.

26. Cantú, C.A., 2001. México, margen occidental de la Pangea según evidencias biogeográficas del Pérmico al Jurásico Inferior, Revista Mexicana del Petróleo (In Spanish), Año XXVI, Núm. 345, pp. 28 - 35.

27. Sillitoe, R.H., 2002. Rifting, bimodal volcanism, and bonanza gold veins: Society of Economic Geologist Newsletter, 48, pp. 24 - 27.

28. Goodfellow, W.D., Peter, J.M., Winchester, J.A. and Van Staal, C.R., 2003. Ambient marine environment and sediment provenance during formation of massive sulfide deposits in the Bathurst Mining Camp: Importance of reduced bottom waters to sulfide precipitation and preservation: Economic Geology Monograph, V. 11, pp. 129 - 156

29. Levinson, A.A., 1980. Introduction to exploration Geochemistry, Applied Publishing, Wilmette, Il, USA, Second edition, pp. 924.

30. Mclenan, S.M., Hemming, S., McDaniel, D.K. and Hanson, G.H., 1993. Geochemical approaches to sedimentation, provenance, and tectonics. Johnsson, M.J., Basu, A. (Eds). Processes controlling the composition of clastic sediments. Geological Society of America.

31. Coleman, M.L., Raiswell, R., Brown, A., Curtis, C.D., Aplin, A.C., Ortoleva, P.J. \& Eglinton, G., 1993. Microbial mineralization of organic matter mechanisms of self-organization and inferred rates of precipitation of diagenetic minerals (and Discussion), Philosophical Transactions of the Royal Society of London A: Mathematical, Physical and Engineering Sciences, 344 (1670), pp. 69 - 87.

32. Carne, R.C. and Cathro, R.J., 1982. Sedimentary-exhalative (Sedex) Zn$\mathrm{Pb}-\mathrm{Ag}$ Deposits, Northern Canadian Cordillera, Canadian Institute of Mining and Metallurgy, Bulletin, Volume 75, pp. 66 - 78.

33. Goodfellow, W.D., 2004. Geology, genesis and exploration of SEDEX deposits, with emphasis on the Selwyn Basin, Canada. Attributes and models of some major deposits in India, Australia and Canada: New Delhi, Narosa Publishing House, pp. 24 -99. 
Your subsequent submission with Crimson Publishers will attain the below benefits

- High-level peer review and editorial services

- Freely accessible online immediately upon publication

- Authors retain the copyright to their work

- Licensing it under a Creative Commons license

- Visibility through different online platforms

- Global attainment for your research

- Article availability in different formats (Pdf, E-pub, Full Text)

- Endless customer service

- Reasonable Membership services

- Reprints availability upon request

- One step article tracking system 